\title{
Osteonecrosis de los maxilares asociada al empleo de bifosfonatos
}

\section{Bisphosphonate-associated osteonecrosis of the jaw}

\author{
J.L. del Castillo Pardo de Vera', J.A. García de Marcos', S. Arroyo Rodríguez², M. Galdeano Arenas', \\ J. Calderón Polanco ${ }^{3}$
}

\begin{abstract}
Resumen: Los bifosfonatos constituyen un grupo de fármacos inhibidores de la resorción ósea, utilizados en el tratamiento de numerosas patologías como la osteoporosis, la enfermedad de Paget, el mieloma múltiple, la hipercalcemia maligna y las metástasis óseas asociadas al cáncer de mama o de próstata. El principal efecto farmacológico de los bifosfonatos es la inhibición de la resorción ósea, mediante una disminución de la actividad de los osteoclastos, sin intervenir en la formación y mineralización del hueso. Son fármacos utilizados a nivel mundial con unos claros beneficios contrastados clínicamente. Numerosas publicaciones durante los últimos tres años, y debido a su utilización masiva, consideran que la osteonecrosis de los maxilares está asociada al tratamiento con bifosfonatos.

Es importante que los pacientes sean informados del riesgo de presentarse esta complicación, para tener la oportunidad de someterse a procedimientos dentales previos al inicio del tratamiento. Las medidas preventivas deben realizarse antes, durante y después del tratamiento con bifosfonatos. El tratamiento quirúrgico debe reservarse para aquellos pacientes que presenten síntomas. Son necesarias nuevas investigaciones que clarifiquen esta complicación.
\end{abstract}

Palabras clave: Bifosfonatos (BF); Osteonecrosis; Ácido zoledrónico.

Recibido: 15.02 .07

Aceptado: 06.03 .07

\begin{abstract}
Bisphosphonates constitute a group of inhibitors of bone resorption that are used for treating many disor-ders such as osteoporosis, Paget's disease, multiple myeloma, malignant hypercalcemia and bone metas-tases associated with breast and prostate cancer. The main pharmacological effect of bisphosphonates is the inhibition of bone resorption, mediated by a decreased function of osteoclasts without interfering in bone formation and mineralization.

These drugs are used worldwide, with clear and clinically proven benefits. Several publications within the last three years consider osteonecrosis of the jaw to be associated with bisphosphonate therapy as a result of their extensive use.

It is important for patients to be informed of the risk of this complication, so that they have the oppor-tunity to assess the need for dental treatment before starting therapy. Preventive measures must be taken before, during, and after treatment with bisphosphonates. Surgical treatment should be reserved for those patients who are symptomatic. Further investigation is needed to completely elucidate this complication.
\end{abstract}

Key words: Bisphosphonates (BP); Osteonecrosis of the jaw; Zoledronic acid.

\footnotetext{
1 Especialista en Cirugía Oral y Maxilofacial.

2 Especialista en Cirugía Oral y Maxilofacial. Jefe de Sección.

3 Especialista en Cirugía Oral y Maxilofacial. Jefe de Servicio.

Doctor en Medicina y Cirugía.

de Albacete, España

Correspondencia:

José Luis del Castillo Pardo de Vera

Complejo Hospitalario Universitario de Albacete, España

c/ Hermanos Falcó, 37

02006 Albacete, España

Email: delcastillo6@hotmail.com
}

Servicio de Cirugía Oral y Maxilofacial. Complejo Hospitalario Universitario 


\section{Introducción}

Los BF constituyen un grupo de fármacos inhibidores de la resorción ósea, que están adquiriendo una relevancia terapeútica cada vez mayor. Se han empleado para la reducción del dolor óseo, la hipercalcemia maligna y las complicaciones esqueléticas en pacientes con mieloma múltiple o enfermedad de Paget, y en el tratamiento de las metástasis óseas asociadas al cáncer de mama o de próstata. ${ }^{1,2}$ La aparición de los BF ha marcado un antes y un después en el tratamiento de las metástasis óseas derivadas del cáncer. ${ }^{3}$ La mayoría de los casos de osteonecrosis descritos se han producido después de haber sido sometidos los pacientes a algún tipo de procedimiento dental y, sobre todo, tras extracciones. Ha sido a comienzos de 2006 cuando han comenzado a aparecer casos de osteonecrosis tras tratamiento con BF orales para el tratamiento de la osteoporosis, la mayoría de forma espontánea. ${ }^{1}$

La estructura del núcleo del BF está formada por dos grupos de fosfato unidos a un solo átomo de carbono (P-C-P). El mecanismo de acción, su potencia biológica y su eficacia clínica depende de la presencia o ausencia de una molécula de nitrógeno en su estructura bioactiva. Los que incorporan nitrógeno en su molécula son los más potentes, entre los que se incluyen el alendronato, ácido zoledrónico y pamidronato.

El mecanismo de acción no está completamente aclarado pero no hay duda que la máxima acumulación se produce en la matriz ósea y, sobre todo, en los osteoclastos, ya que el primer efecto de los BF es una disminución de los mismos. Es ahí donde se depositan con rapidez en las primeras $24-48$ horas $y$, al no ser metabolizados, la concentración ósea se mantiene elevada durante periodos prolongados. ${ }^{3}$

\section{Indicaciones terapéuticas}

Los BF constituyen un grupo de fármacos inhibidores específicos de la actividad osteoclástica ampliamente utilizados a nivel mundial. Producen unos claros beneficios contrastados clínicamente en el tratamiento de numerosas patologías con afectación ósea. Los BF consiguen con la ayuda de analgésicos y otras medidas terapeúticas como la radioterapia, controlar el dolor óseo, el riesgo de fracturas y frenar el desarrollo de nuevas metástasis óseas. ${ }^{3}$ Actualmente las principales indicaciones de los bifosfonatos son:

- En pacientes con mieloma múltiple son eficaces en la reducción del dolor óseo y de las complicaciones esqueléticas. ${ }^{4}$

- En las metástasis óseas asociadas al cáncer de mama o de próstata se consigue disminuir la hipercalcemia, las fracturas y aliviar el dolor, junto con el tratamiento antineoplásico habitual.

- En los casos de hipercalcemia maligna se intenta disminuir la hipercalcemia, reducir el dolor e intentar prevenir el desarrollo de lesiones osteolíticas y fracturas.

- Enfermedad de Paget.

- En casos de osteoporosis corticoidea y postmenopaúsica se intenta prevenir la aparición de dolores óseos y fracturas patológicas.

\section{Introduction}

$B P$ s constitute a group of drugs that inhibit the resorption of bone and their therapeutic relevance is con-tinually increasing. They have been used for reducing bone pain, malignant hypercalcemia and skeletal complications in patients with multiple myeloma or Paget's disease, and for treating bone metastases as-sociated with breast or prostrate cancer. 1,2 The appearance of BPs has marked a before and after in the treatment of bone metastases from cancer. ${ }^{3}$ Most of the osteonecrosis cases described have arisen after patients have undergone some type of dental procedure, especially extractions. It was at the beginning of 2006 that osteonecrosis cases started to appear, which were largely spontaneous, after oral BP treatment for osteoporosis.'

The structure of the BP nucleus is made up of two phosphate groups joined through a single carbon atom (P-C$P$ ). The action mechanism, its biological potency and its clinical efficiency depend on the presence or absence of a nitrogen molecule in its bioactive structure. Those that contain nitrogen in their molecule are stronger, and these include alendronate, zoledronic acid and pamidronate.

The action mechanism has not been completely clarified but there is no doubt that the maximum ac-cumulation arises in the bone matrix, and especially in the osteoclasts, as the first effects of $B P$ are their reduction. It is here that they are deposited during the first 24-48 hours and, as they are not metabolized, bone concentration is kept high for prolonged periods. ${ }^{3}$

\section{Therapeutic indications}

BPs make up a group of drugs that are specific inhibitors of osteoclastic activity that are widely used around the world. They are clearly beneficial for treating numerous pathologies affecting the bones and they have been clinically contrasted. BPs are able to control bone pain, fracture risk and halt the devel-opment of new bone metastases, with the help of analgesics and other therapeutic measures such as radiotherapy. ${ }^{3}$ The principal indications for bisphosphonates are:

- They reduce bone pain and skeletal complications in patients with multiple myeloma. ${ }^{4}$

- They are able to diminish hypercalcemia, fractures and alleviate pain in bone metastases associated with breast or prostrate cancer in conjunction with the usual antineoplastic therapy.

- In cases of malignant hypercalcemia, reducing hypercalcemia and pain should be attempted in addition to preventing the development of osteolytic lesions and fractures.

- Paget's disease.

- In cases of corticoid and postmenopausal osteoporosis an attempt should be made to prevent the ap-pearance of bone pain and pathologic fractures. 


\section{Bifosfonatos (BF)}

Los bifosfonatos más potentes y más utilizados son los de tercera generación, siendo los más empleados el Pamidronato (Aredia ${ }^{\circledR}$ ) y el ácido Zoledrónico (Zometa $\left.{ }^{\circledR}\right) .{ }^{5}$ Ambos se administran tan solo por vía sistémica.

1. Alendronato. Fosamax ${ }^{\circledR}$, produce incrementos en la densidad mineral ósea que se pueden observar transcurridos tan sólo 6 meses del inicio de la terapia. Alendronato, administrado en régimen de dosificación de 70 mg una vez a la semana, es un bisfosfonato que está indicado únicamente en el tratamiento de la osteoporosis postmenopáusica. Actualmente ha demostrado en ensayos clínicos aleatorizados que reducen la incidencia de fracturas osteoporóticas, incluidas las de cadera.

2. Pamidronato. Es uno de los más potentes y se emplea para disminuir el dolor producido por las metástasis óseas asociadas al cáncer de mama y al mieloma múltiple. Solamente se administra de forma intravenosa a dosis entre $60-90 \mathrm{mg}$ en perfusión durante dos horas. Se ha demostrado que reduce y retrasa la aparición de complicaciones esqueléticas como el dolor óseo, las fracturas patológicas y la hipercalcemia.6,7

3. Ácido Zoledrónico. Zometa ${ }^{\circledR}$, es unas 850 veces más potente que el pamidronato, su concentración a nivel óseo es muchísimo más elevada que en plasma y sus niveles descienden lentamente a partir de los seis meses. Se administra en perfusión intravenosa y debido al riesgo del deterioro significativo en la función renal, la dosis única no debe exceder los $4 \mathrm{mg}$ y la duración de la infusión no debe ser inferior a 15 minutos. No está recomendado en pacientes que presenten daño renal grave ni debe utilizarse durante el embarazo.6,7

\section{Mecanismo de acción}

El mecanismo de acción de los BF depende de la presencia o ausencia de una molécula de nitrógeno en su estructura bioactiva. Los no nitrogenados producen toxicidad celular directa al ser metabolizados intracelularmente a sustancias tóxicas. En cambio, los compuestos nitrogenados producen, mediante la inhibición de vías metabólicas específicas de los osteoclastos, la inactivación de estas células y su apoptosis temprana. 5,8

A nivel tisular los BF inhiben la resorción ósea y disminuyen el recambio óseo.

El grado de alteración de la formación del hueso está relacionado con sus efectos sobre el recambio óseo, el cual se encuentra estrechamente asociado con la formación del hueso. A nivel celular actúan sobre los osteoclastos y pueden afectar su función mediante la inhibición del reclutamiento, disminución de su vida media y alteración da la actividad osteoclástica en la superficie ósea. ${ }^{3,9}$ A nivel molecular, se ha postulado que podrían modular la función de los osteoclastos mediante su interacción con un receptor celular o con una enzima intracelular.

Se ha observado a nivel experimental que pueden inhibir la angiogénesis y la supresión de las células endoteliales, lo que se traduce en una necrosis avascular. Además se ha apreciado una disminución del factor de crecimiento vascular en pacientes que han sido tratados con ácido zoledrónico. ${ }^{10-12}$
Bisphosphonates (BP)

The strongest and most used bisphosphonates are third generation, and the most employed are pamidro-nate (Aredia ${ }^{\circledR}$ ) and zoledronic acid (Zometa $\left.{ }^{\circledR}\right)^{5}$ Both are only administered systemically.

1. Alendronate. Fosamax ${ }^{\circledast}$ produces an increase in bone mineral density which can be observed just 6 months after starting treatment. Alendronate, administered at a dose of $70 \mathrm{mg}$ once a week, is a bisphosphonate that is indicated only for treating postmenopausal osteoporosis. Randomized clinical trials are currently demonstrating that the incidence of osteoporotic fractures is reduced, including fractures of the hip.

2. Pamidronate. This is one of the stronger bisphosphonates and it is used to diminish the pain pro-duced by bone metastases associated with breast cancer and multiple myeloma. It is only adminis-tered intravenously using a 60-90 mg dose in perfusion over two hours. It has been demonstrated that it reduces and delays the appearance of skeletal complications such as bone pain, pathological fractures and hypercalcemia. 6,7

3. Zoledronic acid. Zometa ${ }^{\circledR}$ is 850 times stronger than pamidronate. Its concentration level in bone is much higher than in plasma and this descends slowly after six months. It is administered by in-travenous perfusion and, due to the risk of significant deterioration in renal function, the single dose should not exceed $4 \mathrm{mg}$ and the duration of the infusion should not be less than $15 \mathrm{~min}$ utes. It is not recommended for patients that have serious renal damage nor should it be used during pregnancy. ${ }^{6,7}$

\section{Action mechanism}

The action mechanism of BPs depends on the presence or absence of a nitrogen molecule in its bioac-tive structure. Non-nitrogen containing BPs produce direct cellular toxicity on being metabolized intracel-lularly into toxic substances. The nitrogen-containing components on the other hand produce, by means of the inhibition of the specific metabolic pathways of the osteoclasts, the inactivation of these cells and their early apoptosis. 5,8

On a tissular level, BPs inhibit bone resorption and they reduce bone turnover. The degree of distur-bance in bone formation is related with its effects on bone turnover, which is closely associated with bone formation. At a cellular level they act on osteoclasts and they can affect their function by means of re-cruitment inhibition, reduction of the mean life span, and by disrupting osteoclastic activity on bone surfaces. ${ }^{3,9}$ At a molecular level, it has been postulated that they could modulate the function of the osteo-clasts by interacting with a cell receptor or with an intracellular enzyme. At an experimental level it has been observed that they can 


\section{Efectos secundarios de los BF}

Los BF generalmente son fármacos bien tolerados si su administración se realiza de forma correcta. Las reacciones adversas más frecuentes en el tratamiento vía oral corresponden a problemas de tipo digestivo: úlceras gástricas, molestias gastrointestinales o esofagitis. Cuando el tratamiento se realiza vía intravenosa se pueden añadir: síndrome pseudogripal (fiebre, escalofrios, artralgias, mialgias, dolor óseo), fatiga, flebitis, anemia, debilidad, edemas o disnea. ${ }^{6}$ Una complicación menos frecuente pero potencialmente más grave es una afectación de la función renal, en forma de fallo renal o necrosis tubular aguda, que puede aparecer en casos en los que la administración del BF se produce de forma rápida. En los últimos años han aumentado las publicaciones de casos de necrosis ósea localizada en los maxilares en pacientes en tratamiento con BF por patologías como el mieloma múltiple, la hipercalcemia maligna y las metástasis óseas asociadas al cáncer de mama o de próstata (Tabla 1). ${ }^{13}$

\section{Osteonecrosis de los maxilares}

La osteonecrosis maxilar en pacientes en tratamiento con estos fármacos parece estar causada por la combinación de falta de aporte vascular y falta de remodelado y regeneración ósea. ${ }^{2}$ Los maxilares presentan un mayor aporte sanguíneo en comparación con otras estructuras óseas y un remodelado óseo más rápido debido a la estimulación mecánica diaria que producen las piezas dentales insertadas en los mismos durante la masticación, dos circunstancias que aumentan la acción de los BF sobre estos huesos. ${ }^{9}$ Otro factor que favorece la osteonecrosis en esta localización es el hecho de que las arterias mandibulares son arterias terminales. Estas circunstancias, junto con la frecuente presencia de patologías dentales y los tratamientos odontológicos que provocan agresiones físicas sobre el hueso, explican el mayor riesgo de necrosis a nivel de los maxilares, y el que solamente estén separados del medio bucal por una fina capa de mucosa incrementa el riesgo de sobreinfección del hueso necrótico. ${ }^{13}$

La zona con osteonecrosis puede permanecer asintomática durante semanas o meses y tan solo mostrarse como una zona de la mandíbula o el maxilar con exposición ósea con progresión a la formación de un secuestro óseo (Fig. 1). Cuando las defensas locales se encuentran disminuidas por una infección, traumatismo o cirugía los microorganismos pueden invadir el hueso afectado, sobreinfectando la zona y con progresión de la necrosis, agravándose esta circunstancia por el compromiso vascular que supone la inhibición de la angiogénesis por los BF. Los pacientes refieren dolor importante asociado con tumefacción localizada y secreción purulenta. ${ }^{9}$

Tanto la Asociación Dental Americana (ADA) como la Asociación Americana de Cirujanos Orales y Maxilofaciales (AAOMS) han publicado en 2006 una serie de recomendaciones para la práctica dental y una guía de consenso en el manejo de osteonecrosis en pacientes en tratamiento con BF. ${ }^{1}$ Se considera que un paciente puede incluirse dentro de este grupo si cumple estas tres premisas: - Tratamiento previo o en la actualidad con BF. inhibit angiogenesis and the suppression of endothelial cells, which results in avascular necrosis. In addition, a reduction has been observed in the vascular growth factor of patients treated with zoledronic acid. 10-12

\section{Secondary effects of BPS}

$B P s$ are generally well-tolerated drugs if their administration is carried out correctly. The most common adverse reactions in orally taken treatment, relate to problems of a digestive type: gastric ulcers, gastroin-testinal disturbances or esophagitis. When the treatment is carried out intravenously there may be in addi-tion: pseudo-flue syndrome (fever, shivering, arthralgias, myalgias, bone pain), fatigue, phlebitis, anemia, weakness, edemas or dyspnea. ${ }^{6} \mathrm{~A}$ less frequent complication, but one that is potentially more serious, concerns renal function in the form of renal failure or acute tubular necrosis that can appear in cases in which the administration of $B P$ is carried out quickly. Over recent years there has been an increase in published cases of bone necrosis located in the jaws of patients undergoing BP treatment for pathologies such as multiple myeloma, malignant hypercalcemia and bone metastases associated with breast or pros-trate cancer (Table 1).13

\section{Osteonecrosis of the jaw}

Osteonecrosis of the jaw in patients undergoing treatment with these drugs appears to be caused by the combination of a vascular supply deficit and a remodeling and bone regeneration deficit. ${ }^{2}$ The jaw has a greater blood supply compared with other bone structures and faster bone remodeling due to daily me-chanical stimulation produced by the teeth in the jaw during mastication, two circumstances that increase the action of BPs on these bones. ${ }^{9}$ Another factor that favors osteonecrosis in this location is the fact that the arteries of the mandible are terminal arteries. These circumstances, together with the frequent pres-ence of dental pathologies, and odontological therapy that is physically aggressive for the bone, explain the greater risk of necrosis of the jaws, and the fact that they are only separated from the mouth by a fine layer of mucosa increases the risk of additional infection of necrotic bone. ${ }^{13}$

The area with osteoporosis can remain asymptomatic for weeks or months and it can appear as an area of the mandible or maxilla with bone exposure which progresses to sequestered bone (Fig. 1). When local defenses are weakened because of infection, trauma or surgery, microorganisms may invade the affected bone, with further infection of the area leading to necrosis. This is exacerbated by vascular com-promise that entails the inhibition of angiogenesis because of the BPs. The patients report considerable pain 
Tabla 1. Series de casos de osteonecrosis publicados en los últimos años

\begin{tabular}{|c|c|c|c|c|c|}
\hline Autor y año & Casos & Patología & Bifosfonato & Localización & Exodoncias \\
\hline Ruggiero et al. ${ }^{7}$ (2004) & 63 & $\begin{array}{c}\text { Mieloma Múltiple (29) } \\
\text { Ca. Mama (21) } \\
\text { Ca. Próstata (3) } \\
\text { Osteoporosis (7) } \\
\text { Sarcoma uterino(1) } \\
\text { Ca. Pulmón (1) } \\
\text { Leucemia (1) }\end{array}$ & $\begin{array}{l}\text { Pamidronato } \\
\text { Ácido Zoledrónico } \\
\text { Alendronato } \\
\text { Risendronato }\end{array}$ & $\begin{array}{c}\text { Mandíbula (39) } \\
\text { Maxilar (23) } \\
\text { Mandíbula y Maxilar (1) }\end{array}$ & 54 \\
\hline Bagan et al. ${ }^{11}$ (2005) & 10 & $\begin{array}{l}\text { Mieloma Múltiple (2) } \\
\text { Ca. Mama (8) }\end{array}$ & $\begin{array}{l}\text { Pamidronato } \\
\text { Ácido Zoledrónico }\end{array}$ & $\begin{array}{c}\text { Mandíbula (5) } \\
\text { Mandíbula y Maxilar (5) }\end{array}$ & 7 \\
\hline Marx et al. ${ }^{12}(2003)$ & 36 & $\begin{array}{c}\text { Mieloma Múltiple (18) } \\
\text { Ca. Mama (17) } \\
\text { Osteoporosis (1) }\end{array}$ & $\begin{array}{l}\text { Pamidronato } \\
\text { Ácido Zoledrónico }\end{array}$ & $\begin{array}{c}\text { Mandíbula (29) } \\
\text { Maxilar (5) } \\
\text { Mandíbula y Maxilar (2) }\end{array}$ & 28 \\
\hline Carter et al. ${ }^{13}(2003,2005)$ & 5 & $\begin{array}{l}\text { Mieloma Múltiple (2) } \\
\text { Enfermedad Paget (3) }\end{array}$ & $\begin{array}{l}\text { Pamidronato } \\
\text { Alendronato }\end{array}$ & $\begin{array}{c}\text { Maxilar (4) } \\
\text { Mandíbula y Maxilar (1) }\end{array}$ & 4 \\
\hline Lugassy et al. ${ }^{15}$ (2004) & 3 & Mieloma Múltiple (3) & $\begin{array}{l}\text { Pamidronato } \\
\text { Ácido Zoledrónico }\end{array}$ & Mandíbula (3) & 1 \\
\hline Maereovet ${ }^{16}(2005)$ & 9 & $\begin{array}{c}\text { Mieloma Múltiple (4) } \\
\text { Ca. Mama (5) }\end{array}$ & $\begin{array}{l}\text { Pamidronato } \\
\text { Ácido Zoledrónico }\end{array}$ & No especificado & 0 \\
\hline Melo et al. ${ }^{17}(2005)$ & 1 & Ca. Mama (1) & Ácido Zoledrónico & Maxilar (1) & 1 \\
\hline Sanna et al. ${ }^{18}(2005)$ & 10 & Ca. Mama (10) & $\begin{array}{l}\text { Pamidronato } \\
\text { Ácido Zoledrónico }\end{array}$ & $\begin{array}{l}\text { Mandíbula (9) } \\
\text { Maxilar (1) }\end{array}$ & 4 \\
\hline Vanucchi et al. ${ }^{19}$ (2005) & 1 & Mieloma Múltiple (1) & Ácido Zoledrónico & Mandíbula (1) & 1 \\
\hline Migliorati et al. ${ }^{25}(2003,2005)$ & 18 & $\begin{array}{l}\text { Mieloma Múltiple (3) } \\
\text { Ca. Mama (10) } \\
\text { Ca. Próstata (1) } \\
\text { Osteoporosis (1) } \\
\text { Ca. Ovario (1) } \\
\text { Ca. Ovario y Mama (1) } \\
\text { Ca. Próstata-Linfoma (1) }\end{array}$ & $\begin{array}{c}\text { Pamidronato } \\
\text { Ácido Zoledrónico }\end{array}$ & $\begin{array}{c}\text { Mandíbula (8) } \\
\text { Maxilar (2) } \\
\text { Mandíbula y Maxilar (3) } \\
\text { No especificado (7) }\end{array}$ & 7 \\
\hline
\end{tabular}

Table 1. Series of osteonecrosis cases published in recent years

\begin{tabular}{|c|c|c|}
\hline Author and year & Cases & Pathology \\
\hline Ruggiero et al. ${ }^{7}$ (2004) & 63 & $\begin{array}{c}\text { Multiple myeloma (29) } \\
\text { Ca. Breast (21) } \\
\text { Ca. Prostate (3) } \\
\text { Osteoporosis (7) } \\
\text { Uterine sarcoma (1) } \\
\text { Ca. Lung (1) } \\
\text { Leukemia (1) }\end{array}$ \\
\hline Bagan et al. ${ }^{11}$ (2005) & 10 & $\begin{array}{l}\text { Multiple myeloma (2) } \\
\text { Ca. Breast (8) }\end{array}$ \\
\hline Marx et al. ${ }^{12}$ (2003) & 36 & $\begin{array}{c}\text { Multiple myeloma (18) } \\
\text { Ca. Breast (17) } \\
\text { Osteoporosis (1) }\end{array}$ \\
\hline Carter et al. ${ }^{13}(2003,2005)$ & 5 & $\begin{array}{c}\text { Multiple myeloma (2) } \\
\text { Paget's disease (3) }\end{array}$ \\
\hline Lugassy et al. ${ }^{15}$ (2004) & 3 & Multiple myeloma (3) \\
\hline Maereovet. ${ }^{16}$ (2005) & 9 & $\begin{array}{l}\text { Multiple myeloma (4) } \\
\text { Ca. Breast (5) }\end{array}$ \\
\hline Melo et al. ${ }^{17}$ (2005) & 1 & Ca. Breast (1) \\
\hline Sanna et al..$^{18}(2005)$ & 10 & Ca. Breast (10) \\
\hline Vanucchi et al. ${ }^{19}$ (2005) & 1 & Multiple myeloma (1) \\
\hline Migliorati et al. ${ }^{25}(2003,2005)$ & 18 & $\begin{array}{c}\text { Multiple myeloma (3) } \\
\text { Ca. Breast (10) } \\
\text { Ca. Prostrate (1) } \\
\text { Osteoporosis (1) } \\
\text { Ca. Ovary (1) } \\
\text { Ca. Ovary and Breast (1) } \\
\text { Ca. Prostate-Lymphoma (1) }\end{array}$ \\
\hline
\end{tabular}

\section{Bisphosphonate}

Pamidronate

Zoledronic Acid

Alendronate

Risedronate

Pamidronate

Zoledronic Acid

Pamidronate

Zoledronic Acid

Pamidronate

Alendronate

Pamidronate

Zoledronic Acid

Pamidronate

Zoledronic Acid

Zoledronic Acid

Pamidronate

Zoledronic Acid

Zoledronic Acid

Pamidronate

Zoledronic Acid

\section{Location \\ Mandible (39) \\ Maxilla (23) \\ Mandible and maxilla (1)}

Extractions

54

7

Mandible and maxilla (5)

Mandible (29)

Maxilla (5)

Mandible and maxilla (2) Maxilla (4)

Mandible and Maxilla (1) Mandible (3)

Not specified

Maxilla (1)

Mandible (9)

Maxilla (1)

Mandible (1)

Mandible (8)

Maxilla (2)

Mandible and maxilla (3)

Not specified (7)
0

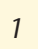

4

1

7 
- Exposición ósea en el área maxilofacial que persiste más de ocho semanas.

- No existencia de antecedentes de radioterapia a nivel de los maxilares. Se ha estimado que la incidencia de osteonecrosis en pacientes en tratamiento con BF intravenosos varía entre 0,8 y $12 \%$. En el caso de tratamiento oral, la compañía farmaceútica Merck publicó que los posibles casos en pacientes en tratamiento con Alendronato (el bifosfonato oral más prescrito) era aproximadamente 170 casos a nivel mundial, la mayoría de ellos de forma espontánea; la incidencia se calculaba en torno a 0,7 personas por cada 100.000 y por año de exposición al fármaco. ${ }^{1}$

\section{Factores de riesgo para el desarrollo de osteonecrosis}

A. Factores relacionados con el fármaco

- Potencia del BF: el ácido zoledrónico (Zometa ${ }^{\circledR}$ ) es uno de los BF sistémicos más empleado en la actualidad y es unas 850 veces más potente que pamidronato. Este último es más potente que los administrados vía oral.

- Duración: tratamientos muy prolongados parecen asociarse a un aumento del riesgo de osteonecrosis. ${ }^{20,21}$

B. Factores locales

- Cirugía oral: exodoncias, cirugía periapical, cirugía periodontal y colocación de implantes dentales.1,2

- Factores anatómicos: torus palatinos y/o linguales. La necrosis suele presentarse más frecuentemente a nivel mandibular que maxilar (2:1) y sobre todo en zonas óseas más prominentes.

- Patología oral: procesos traumáticos, inflamatorios o infecciosos a nivel dental y/o oral.

C. Factores demográficos y sistémicos

- Edad: casos de mieloma múltiple y recibiendo BF el riesgo aumenta un $9 \%$ con cada década.

- Raza: más frecuente en la caucásica.

- Tipo de proceso oncológico: mayor riesgo en casos de mieloma múltiple seguido por cáncer de mama.

- Osteopenia/osteoporosis asociada al proceso oncológico.

- Factores sistémicos: tratamiento corticoideo, diabetes, tabaco, alcohol, mala higiene oral, enfermedad periodontal, radioterapia en cabeza y cuello, coagulopatías y quimioterapia concomitante.

\section{Material y método}

Presentamos doce casos de pacientes que presentaban osteonecrosis en los maxilares en tratamiento con BF por diversas patologías, tratados en el Servicio de Cirugía Oral y Maxilofacial del Hos- associated with localized swelling and purulent secretions. ${ }^{9}$

In 2006 the American Dental Association (ADA) as well as the American Association of Oral and Maxillofacial Surgeons (AAOMS) published a series of recommendations for dental practice and a posi-tion paper on the management of osteonecrosis for patients undergoing bisphosphonate therapy. ${ }^{1}$ A patient can be included in this group if the following three premises are met:

- Current or previous treatment with a BP.

- Exposed bone in the maxillofacial region that has persisted for more than eight weeks.

- No history of radiation therapy to the jaw.

It has been estimated that the incidence rate of osteonecrosis in patients taking intravenous BPs varies between 0.8 and $12 \%$. In the case of oral therapy, the pharmaceutical company Merck published that the possible cases of patients taking Alendronate (the most prescribed bisphosphonate) was approximately 170 cases on a worldwide level, most of these in a spontaneous fashion; the incidence rate was calculated as around $0.7 \%$ of every 100.000 people per year of exposure to the drug.

Risk factors for developing osteonecrosis

A. Factors related with the drug

- BP strength: zoledronic acid (Zometa ${ }^{\circledR}$ ) is currently one of the most used systemic BPs and it is 850 times stronger than pamidronate, which is the strongest of those taken orally.

- Duration: very prolonged treatment appears to be associated with an increase in the risk of osteone-crosis. ${ }^{20,21}$

B. Local factors

- Oral surgery: extractions, periapical surgery, periodontal surgery and the placement of dental implants. ${ }^{1,2}$

- Anatomic factors: palatal and/or lingual torus. The necrosis tends to appear most commonly in the mandible rather than the maxilla (2:1) especially in bone areas that are more prominent.

- Oral pathology: trauma, inflammatory or infectious conditions affecting the teeth and/or mouth.

C. Demographic and systemic factors

- Age: with multiple myeloma cases taking BP the risk increases by $9 \%$ each decade. 
pital Universitario de Albacete, desde Marzo hasta Octubre de 2006. Todos los pacientes han sido remitidos a nuestra consulta procedentes de los Servicios de Oncología Médica y Medicina Interna para valoración de las lesiones en los maxilares. La edad media de los pacientes era de 65 años, con un rango entre 49 y 77 años. Se trata de cuatro varones y ocho mujeres, que estaban en tratamiento con diferentes BF (alendronato, pamidronato y ácido zoledrónico) por las siguientes patologías: 4 pacientes presentaban metástasis por cáncer de mama, 3 presentaban metástasis por cáncer de próstata, 4 sufrían mieloma múltiple y un solo caso recibía tratamiento por osteoporosis.

\section{Resultados}

En todos los casos la sintomatología consistía en dolor e inflamación junto con exposición ósea; 9 pacientes presentaban supuración y dos de ellos fístula cutánea activa. En un $58,3 \%$ se afectó exclusivamente la mandíbula, $25 \%$ el maxilar y en un $16,6 \%$ ambos. Como factores desencadenantes en el $66,6 \%$ de los casos se habían realizado con anterioridad exodoncias en la misma localización que la exposición ósea. La mayoría de los pacientes recibían tratamiento con quimioterapia $(83,3 \%)$, radioterapia $(16,6 \%)$ o corticoides $(33,3 \%)$, de forma aislada o asociados. Las imágenes de la OPG y de TAC evidenciaban la presencia de un patrón moteado o lítico en la zona ósea expuesta (Figs. 2 y 3).

En todos los casos se instauró tratamiento con antibióticos y enjuagues con clorhexidina. Tras el seguimiento de las lesiones tan solo se realizó tratamiento mínimamente agresivo en los casos más rebeldes al tratamiento conservador: en 1 paciente se realizó curetaje del alvéolo postextracción, en 5 pacientes desbridamiento limitado de las zonas necróticas expuestas que producían roce y en un solo caso se realizó una resección del secuestro óseo (Tablas 2 y 3 ). Todos los procedimientos se llevaron a cabo bajo la administración de antibióticos orales, amoxicilina asociada con ácido clavulánico, salvo en un paciente alérgico a los beta-lactámicos que recibió clindamicina.

En todos los casos se ha conseguido controlar la sintomatología dolorosa y la secrección purulenta, pero permanece la exposición ósea. Los pacientes continúan realizando enjuagues orales con clorhexidina al $0,12 \%$, en ningún caso se ha producido un aumento de la zona expuesta y tan solo precisan la administración de analgésicos habituales para controlar las molestias en la cavidad oral.
- Race: more com mon in Caucasians.

- Type of oncological process: greater risk in cases of multiple myeloma followed by breast cancer.

- Osteopenia/osteoporosis associated with oncological processes.

- Systemic factors: corticoid therapy, diabetes, tobacco, alcohol, bad oral hygiene, periodontal disease, radiotherapy to the head and neck, coagulation therapy and concomitant chemotherapy.

\section{Material and methods}

Twelve cases are presented of patients with osteonecrosis of the jaw who were undergoing $B P$ treat-ment for various pathologies. They were treated by the department of Oral and Maxillofacial Surgery of the University Hospital of Albacete between March and October 2006. All these patients were referred by the department of Medical Oncology and Internal Medicine for an evaluation of their jaw lesions. The mean age of the patients was 65 , and the age range was between 49 and 77 . There were 4 males and 8 females who were undergoing treatment with different BPs (alendronate, pamidronate and zoledronic acid) for the following pathologies: 4 patients had metastases from breast cancer, 3 had metastases from prostrate cancer, 4 had multiple myeloma and 1 was receiving treatment for osteoporosis.

In all cases the symptomatology consisted in pain and inflammation together with bone exposure; 9 patients had suppuration and two had active cutaneous fistulas. In 58.3\% this affected the mandible ex-clusively, 25\% the maxilla and in $16.6 \%$ both. With regard to causative factors, $66.6 \%$ of cases had pre-viously had extractions in the same area with the bone exposure. Most patients had received chemotherapy (83.3\%), radiotherapy (16.6\%) or corticoid therapy (33.3\%), either alone or combined. The OPT and CAT scan images showed an exposed area of bone that was mottled or lytic (Figs. 2 and 3). 
Tabla 2. Casuística. (P: paciente; E/S: edad/sexo; BF: bifosfonato)

\begin{tabular}{|c|c|c|c|c|c|c|}
\hline $\mathbf{P}$ & $E / S$ & Diagnóstico & $\mathrm{BF}$ & Duración $\mathrm{tt}^{\circ}$ & Localización & Factor riesgo \\
\hline 2 & $64 / \mathrm{M}$ & MTS Ca. Mama & Ácido Zoledrónico & 4 años & $\mathrm{MD}$ & QT \\
\hline 4 & $49 / \mathrm{V}$ & Mieloma Múltiple & Ácido Zoledrónico & 8 meses & $M X$ & QT \\
\hline 5 & $75 / \mathrm{V}$ & Mieloma Múltiple & Ácido Zoledrónico & 2,5 años & $M X$ & $\mathrm{QT}+$ Corticoides \\
\hline 6 & $77 / \mathrm{V}$ & MTS Ca. Próstata & Ácido Zoledrónico & 8 meses & $\mathrm{MD} / \mathrm{MX}$ & $\mathrm{QT}+$ Corticoides+RT \\
\hline 7 & $76 / \mathrm{M}$ & Osteoporosis & Alendronato & 6 años & MD & - \\
\hline 10 & $63 / \mathrm{M}$ & MTS Ca. Próstata & Ácido Zoledrónico & 4 años & $\mathrm{MD}$ & QT \\
\hline 11 & $57 / \mathrm{M}$ & MTS Ca. Mama & Pamidronato & 3,5 años & MD & QT + Corticoides \\
\hline 12 & $66 / \mathrm{M}$ & Mieloma Múltiple & Ácido Zoledrónico & 4,5 años & MD & QT \\
\hline
\end{tabular}

Table 2. Casuistry. (P: patient; A/S: age/sex; BP: bisphosphonate)

\begin{tabular}{|c|c|c|c|c|c|c|}
\hline$P$ & $A / S$ & Diagnosis & $B P$ & Tt duration & Location & Risk factor \\
\hline 1 & $73 / M$ & MTC Ca. Prostate & Zoledronic Acid & 3 years & $M D / M X$ & $R T$ \\
\hline 2 & $64 / F$ & MTC Ca. Breast & Zoledronic Acid & 4 years & $M D$ & $\mathrm{CHT}$ \\
\hline 3 & $52 / F$ & MTC Ca. Breast & Zoledronic Acid & 3.5 years & $M X$ & $\mathrm{CHT}$ \\
\hline 4 & $49 / M$ & Multiple myeloma & Zoledronic Acid & 8 months & $M X$ & $\mathrm{CHT}$ \\
\hline 5 & $75 / M$ & Multiple myeloma & Zoledronic Acid & 2.5 years & $M X$ & $\mathrm{CHT}+$ Corticoid drugs \\
\hline 6 & $77 / M$ & MTC Ca. Prostate & Zoledronic Acid & 8 months & $M D / M X$ & $C H T+$ Corticoid drugs $+R T$ \\
\hline 7 & $76 / F$ & Osteoporosis & Alendronate & 6 years & $M D$ & - \\
\hline 8 & $53 / F$ & MTC Ca. Breast & Zoledronic Acid & 7 years & $M D$ & CHT + Corticoid drugs \\
\hline 9 & $76 / F$ & Multiple myeloma & Zoledronic Acid & 3 years & $M D$ & $\mathrm{CHT}$ \\
\hline 10 & $63 / F$ & MTC Ca. Prostate & Zoledronic Acid & 4 years & $M D$ & $\mathrm{CHT}$ \\
\hline 11 & $57 / F$ & MTC Ca. Breast & Pamidronate & 3.5 years & $M D$ & CHT + Corticoid drugs \\
\hline 12 & $66 / F$ & Multiple myeloma & Zoledronic Acid & 4.5 years & $M D$ & $\mathrm{CHT}$ \\
\hline
\end{tabular}

Tabla 3. Casuística. (+++ intenso, ++ moderado, + leve; ---ausencia)

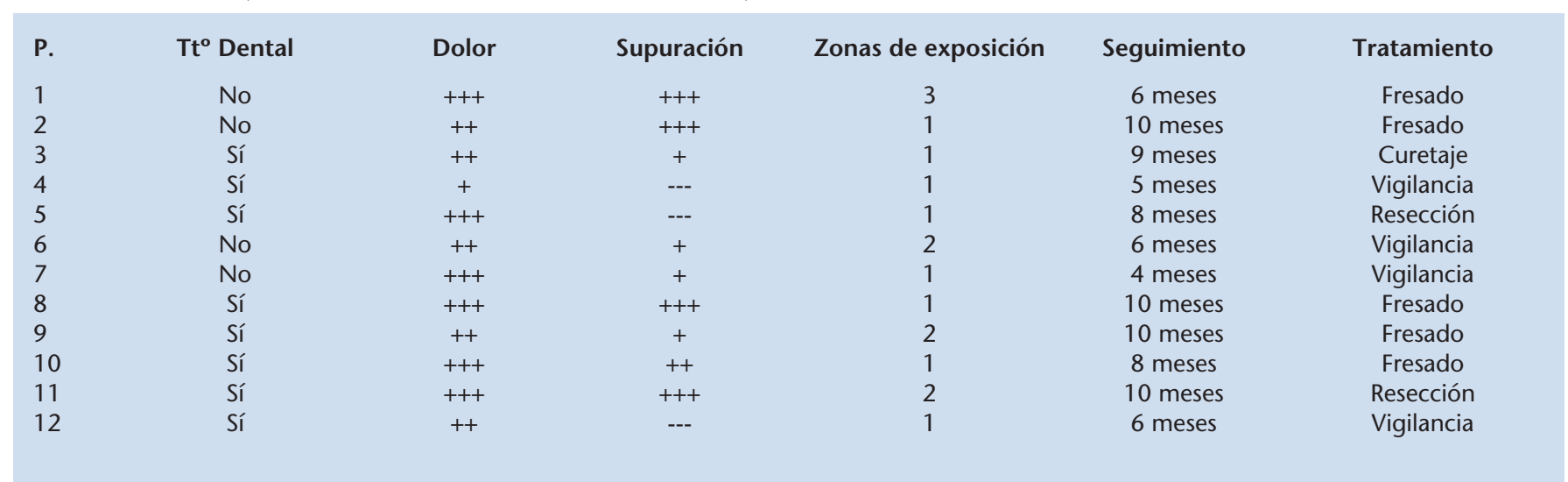

Table 3. Casuistry. (+++ intense, ++ moderate, + light; ---absence)

\begin{tabular}{|c|c|c|c|c|c|c|}
\hline$P$. & Dental Tt & Pain & Suppuration & Areas exposed & Follow-up & Treatment \\
\hline 1 & No & +++ & +++ & 3 & 6 months & Drilling \\
\hline 2 & No & ++ & +++ & 1 & 10 months & Drilling \\
\hline 3 & Yes & ++ & + & 1 & 9 months & Curettage \\
\hline 4 & Yes & + & --- & 1 & 5 months & Observation \\
\hline 5 & Yes & +++ & --- & 1 & 8 months & Resection \\
\hline 6 & No & ++ & + & 2 & 6 months & Observation \\
\hline 7 & No & +++ & + & 1 & 4 months & Observation \\
\hline 8 & Yes & +++ & +++ & 1 & 10 months & Drilling \\
\hline 9 & Yes & ++ & + & 2 & 10 months & Drilling \\
\hline 10 & Yes & +++ & ++ & 1 & 8 months & Drilling \\
\hline 11 & Yes & +++ & +++ & 2 & 10 months & Resection \\
\hline 12 & Yes & ++ & -- & 1 & 6 months & Observation \\
\hline
\end{tabular}




\section{Medidas preventivas previas al inicio del tratamiento con BF}

Tan pronto como el especialista decida el tratamiento con BF el paciente debe ser remitido a un odontólogo o cirujano maxilofacial para la realización de una exploración exhaustiva de la cavidad oral y del estado dental. El inicio del tratamiento se retrasará, siempre que el estado general del paciente lo permita, hasta que se hayan completado y realizado todos los procedimientos quirúrgicos orales y los tratamientos dentales correspondientes. ${ }^{3}$

La exploración debe constar de una completa exploración clínica y radiológica, con radiografías panorámicas y/o periapicales. El tratamiento dental irá encaminado a evitar la aparición de posibles infecciones y prevenir la necesidad de procedimientos dentales invasivos a corto y medio plazo. Se incluyen dentro del tratamiento las exodoncias de las piezas dentales en mal estado, cirugía periodontal, endodoncias, restauraciones de caries, limpiezas dentales y el ajuste correcto de las prótesis. Se deben revisar de forma exhaustiva todas las zonas de apoyo de las prótesis dentales, tanto completas como parciales, a fin de prevenir traumatismos en la mucosa. $1,2,13$

Debe evitarse en estos pacientes la colocación de implantes osteointegrados, ya que el riesgo de producirse la osteonecrosis en la zona de implantación es elevada.7 Se debe comentar con el paciente la situación actual y discutir los riesgos, beneficios y tratamientos alternativos. Las revisiones tras su colocación serán más frecuentes de lo habitual, para detectar precozmente una posible periimplantitis. 1,13

Las piezas incluidas sin erupcionar cubiertas en su totalidad por hueso o encía no deben ser exodonciadas, pero sí aquellas que presenten comunicación con la cavidad oral. Todas las intervenciones deben ser realizadas al menos un mes antes del inicio del tratamiento. El paciente debe acudir a revisiones por parte de su odontólogo y se insistirá en que comunique lo antes posible cualquier síntoma doloroso, inflamatorio o zona de exposición ósea. ${ }^{2}$

La administración de antibióticos de manera profiláctica antes de los procedimientos odontológicos no invasivos no está indicada, pero sí se recomienda en el caso de someterse a algún procedimiento dental invasivo o quirúrgico. El antibiótico de elección es la penicilina. En el caso de alergia a la penicilina se recomiendan combinaciones de eritromicina con metronidazol ó quinolonas con metronidazol. ${ }^{1,22}$

Son pocos los casos de osteonecrosis espontánea en caso de tratamiento intravenoso y la mayoría se desencadenan como complicación de una intervención dentoalveolar (Fig. 4). Por ello el inicio del tratamiento se retrasará, siempre que el estado general del paciente lo permita, hasta que finalicen dichos procedimientos.

\section{Protocolos terapéuticos}

\section{Pacientes asintomáticos con BF intravenosos}

Los oncólogos deberían remitir a los pacientes en tratamiento intravenoso con $\mathrm{BF}$ al odontólogo o al cirujano maxilofacial para una exploración exhaustiva de la cavidad oral. En ella se buscarán exposiciones óseas en las localizaciones más frecuentes y se reali-

\section{Results}

In all cases antibiotic therapy and chlorhexidine rinses were started. After following the lesions, only minimally aggressive therapy was carried out in those cases that were more recalcitrant to conservative therapy: in one patient curettage of the extraction socket was carried out, in 5 patients debridement was carried out just of the necrotic areas that had been exposed and that were rubbing, and in just one case was resection of the sequestered bone carried out (Tables 2 and 3). All the procedures were carried out with oral antibiotics, amoxicillin in conjunction with clavulanic acid, except for one patient who was allergic to betalactams, who was given clindamycin.

In all cases the painful symptoms were controlled together with the purulent secretion, but bone expo-sure remained. The patients continued with oral rinses with chlorhexidine at $0.12 \%$. There was no in-crease in the exposed area in any of the cases and only the usual painkillers were given to control the dis-comfort in the oral cavity.

\section{Preventative measures before starting bp therapy}

As soon as the specialist decides on BP therapy, the patient should be referred to a dentist or maxillofacial surgeon for an extensive examination of the oral cavity and of the state of the teeth. Starting the treatment should be delayed, if the general condition of the patient allows this, until all the surgical procedures of the mouth and teeth have been carried out. ${ }^{3}$

The examination should include a complete clinical and radiological examination with panoramic and/or periapical radiographs. The dental treatment should be aimed at avoiding the appearance of possi-ble infections and any invasive dental procedures in the short or medium term should be prevented. Any extractions of teeth in bad condition should be included, periodontal surgery, root canal treatment, restorative caries treatment, cleaning and correct adjustment of prostheses. All the supporting areas of the dental prostheses should be thoroughly checked, complete as well as partial prostheses, in order to pre-vent trauma to the mucosa. ${ }^{1,2,13}$

Placing osteointegrated implants in these patients should be avoided, as the risk of osteonecrosis aris-ing in the area of the implant is high.7 The current situation should be discussed with the patient, together with the risks, benefits and alternative therapies. The check-ups after placement should be more frequent than usual, in order to detect any periimplantitis promptly. ${ }^{1,13}$

Unerupted, embedded teeth that are completely covered by bone or gums should not be extracted, but those that are in contact with the oral cavity should be. All interventions should be carried out at least one month before starting treatment. The patient should attend dental check-ups and 
zarán pruebas radiológicas para poner en evidencia imágenes de osteolisis, osteoesclerosis, aumento del espacio periodontal o de la furca. La mejor actitud es mantener una buena higiene oral y un buen estado dental. ${ }^{2}$ En todos los pacientes se deberían seguir las siguientes recomendaciones:

- Las piezas dentales cariadas que no puedan ser restauradas no deben ser exodonciadas, y se realizará la sección de la corona y el tratamiento endodóntico de las raíces. ${ }^{4,13}$

- En el caso de piezas dentales con ligera movilidad se intentará ferulización con acrílico.

- En piezas con mayor movilidad y/o con un quiste apical o un absceso periodontal aumenta el riesgo de desarrollar necrosis, y se debe exodonciar la pieza bajo tratamiento antibiótico.

- Deben ser revisadas todas las prótesis, rebajando las zonas en las que se produzca una excesiva presión o roce, ajustándolas periódicamente. ${ }^{4}$

- Todos los procedimientos quirúrgicos que impliquen al hueso como la exodoncia de cordales incluidos, la extirpación de torus, la cirugía periodontal o la colocación de implantes osteointegrados deben ser evitados.

- En estos pacientes se seguirá la misma pauta de antibióticos que en los pacientes que no han iniciado el tratamiento con BF.

\section{Pacientes asintomáticos con BF orales}

El riesgo de desarrollar osteonecrosis en los maxilares es menor en los pacientes que reciben BF de forma oral. Las intervenciones de cirugía oral no están contraindicadas en estos pacientes, pero deben ser informados del riesgo de desarrollar osteonecrosis inducida por los BF tras las mismas. ${ }^{7}$ Este riesgo aumenta cuando el tratamiento se prolonga durante años. Si el estado del paciente lo permite se ha propuesto que una interrupción de la administración del BF dos o tres meses antes y después de una intervención dental o

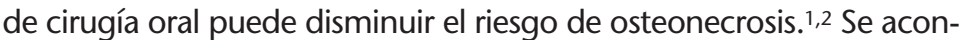
sejan enjuagues con clorhexidina durante dos meses tras la cirugía.

- BF oral durante menos de tres años y sin factores de riesgo: todos los procedimientos dentales, quirúrgicos o periodontales pueden ser realizados sin interrupción del tratamiento.

- BF oral durante menos de tres años y con factores de riesgo: en presencia de factores de riesgo sistémicos y si el estado general del paciente lo permite, se debe valorar la interrupción del tratamiento durante al menos 2 ó 3 meses antes de cualquier tipo de intervención. No se reanudará su administración hasta que se compruebe un buen estado óseo.

- BF oral durante más de tres años con/sin factores de riesgo sistémicos: y si el estado general del paciente lo permite, se debe valorar la interrupción del tratamiento durante al menos 2 ó 3 meses antes de cualquier tipo de intervención. any symptoms of pain, inflammation or any areas with bone exposure should be reported straight away. ${ }^{2}$ The administration of prophylactic antibiotics before non-invasive odontogenic procedures is not in-dicated, but it is recommended for invasive or surgical dental procedures. The antibiotic of choice is peni-cillin. In cases of penicillin allergy, combinations of erythromycin with metronidazole or quinolones with metronidazole are recommended. ${ }^{1,22}$

There are very few cases of spontaneous osteonecrosis in intravenous therapy cases and most arise as a result of complications after dentoalveolar surgery (Fig. 4). The start of the treatment should be de-layed, providing the general health of the patient permits this, until these procedures have been finished.

\section{Therapeutic protocols}

Asymptomatic patients with intravenous bps

Oncologists should refer patients undergoing treatment with intravenous BPs to a dentist or maxillofacial surgeon for an exhaustive examination of the oral cavity. Bone exposure will be looked for in the most common sites and radiology tests will be carried out in order to detect any evidence of osteolysis, osteo-sclerosis, or an increase in the periodontal or furcation space. The best attitude is to maintain good oral hygiene and to keep teeth in good condition. ${ }^{2}$ The following recommendations should be used for all pa-tients:

- Teeth with caries that cannot be restored should not be extracted. The crown should be opened and root canal treatment carried out. 4,13

- Teeth that move slightly should be secured with an acrylic splint.

- With more mobile teeth and/or a periapical cyst or a periodontal abscess there is a greater risk of developing necrosis, and the tooth should receive root canal therapy with antibiotic treatment.

- All prostheses should be checked, and the areas with excessive pressure or that are rubbing should be reduced and adjusted periodically. ${ }^{4}$

- All surgical procedures that involve the bone such as the extraction of embedded wisdom teeth, tori removal, periodontal surgery or the placement of osteointegrated implants should be avoided.

- These patients should be given the same dose of antibiotics as those not undergoing BP treatment. 


\section{Pacientes con osteonecrosis establecida inducida por BF}

El tratamiento de la osteonecrosis establecida intenta disminuir o eliminar la sensación dolorosa, controlar la inflamación y/o infección del hueso y las partes blandas y controlar la progresión de la necrosis ósea. Se trata de una complicación de difícil manejo. El desencadenante de la necrosis ósea en la mayor parte de los pacientes es una actuación quirúrgica por parte del odontólogo, estomatólogo o del cirujano maxilofacial. ${ }^{21}$ La mayor parte de intentos de controlar y disminuir las zonas óseas necróticas por medio de legrados, fresados o cobertura con colgajos locales de tejido blando suelen resultar ineficaces. Deben realizarse solamente cuando el dolor es refractario al resto de tratamientos no quirúrgicos. $7,11 \mathrm{El}$ desbridamiento quirúrgico no consigue en ocasiones un margen quirúrgico vascularizado, ya que la totalidad del maxilar está bajo la influencia del fármaco. Según Ruggiero es extremadamente difícil, aunque no imposible, lograr una resección quirúrgica con hueso viable en los márgenes. Se administrarán analgésicos para tratar el dolor. $1,2,5,21$

Las zonas necróticas expuestas que produzcan roce e inflamación de la encía, la mucosa oral o lingual deben ser regularizadas, incluso a pesar del riesgo de aumentar la exposición del hueso. Los fragmentos de secuestro óseo deben ser retirados, sin manipular el hueso adyacente. La gran mayoría de actuaciones suele producir el aumento de la zona necrótica expuesta o la aparición de zonas nuevas. Por todos estos motivos, los tratamientos quirúrgicos o dentales agresivos deben retrasarse o evitarse en la medida de lo posible. ${ }^{23}$ En caso de someterse a alguna intervención quirúrgica en la cavidad oral puede instaurarse un antibiótico profiláctico 1 o 2 días antes. La administración de antibióticos, de forma continua o intermitente, puede ser beneficiosa en algunos casos de osteonecrosis establecida. Se recomienda la toma de muestras para realizar cultivos con el fin de administrar el antibiótico específico. La mayoría de los gérmenes aislados son sensibles a los betalactámicos y por ello el antibiótico de elección es la amoxicilina, sola o asociada con ácido clavulánico, a dosis de $500 \mathrm{mg}$ tres veces al día y recomendando enjuagues con clorhexidina al 0,12\%. Se puede asociar en los casos más rebeldes metronidazol a dosis de $250 \mathrm{mg}$ tres veces al día. En pacientes alérgicos puede emplearse la clindamicina (300 mg tres veces al dia) o azitromicina (250 mg una vez al día). El tratamiento antibiótico se mantendrá durante dos semanas. Según Marx la asociación de antibióticos y desbridamientos limitados son la mejor opción de tratamiento de las zonas necróticas expuestas. ${ }^{2}$ El tratamiento con oxígeno hiperbárico, que tan buenos resultados produce en casos de osteoradionecrosis $\mathrm{u}$ osteomielitis, no ha demostrado ser eficaz en el tratamiento de necrosis inducida por los BF. 24,25

\section{Discusión}

En los últimos años se ha descrito una nueva complicación como parte del tratamiento de diversas patologías (mieloma múltiple, metástasis de cáncer de mama y próstata, osteoporosis, hipercalcemia maligna, enfermedad de Paget...), la osteonecrosis de los maxilares. En todos los casos el único factor en común utilizado fue-
Asymptomatic oral bp patients

There is less risk of developing osteonecrosis in the jaw if patients are receiving BPs orally. Oral surgery interventions are not contraindicated in these patients, but they should be informed of the risk of developing osteonecrosis after taking, and as a result of, BPs. ${ }^{7}$ This risk increases when the treatment is prolonged over years. It has been suggested that, depending on the patient's condition, interrupting the administration of BPs for two or three months before and after a dental or oral surgery, can reduce the risk of osteonecrosis. ${ }^{1,2}$ Chlorhexidine rinses are recommended for the first two months after surgery.

- Oral BP for less than three years and with no risk factors: all the dental, surgical or periodontal procedures can be carried out without interrupting the treatment.

- Oral BP for less than three years and with risk factors: if there are systemic risk factors and if the general condition of the patient allows it, the interruption of the treatment for at least two or three weeks should be evaluated before any type of intervention. This should not be restarted until bone in a satisfactory condition has been confirmed.

- Oral BP for more than three years with/or without systemic risk factors: if the general health of the patient permits it, interrupting the treatment for at least 2 or 3 months should be evaluated before any type of intervention.

Patients with established osteonecrosis induced by BPS

The treatment that has been established for osteonecrosis attempts to diminish or eliminate the sensa-tion of pain, to control the inflammation and/or infection of bone and soft tissue and to control the pro-gression of bone necrosis. This is a complication that is difficult to manage. Generally in most patients it is triggered by an action by the odontologist, dentist, or maxillofacial surgeon. ${ }^{21}$ Most of the attempts at controlling or diminishing the necrotic bone areas by means of curettage, drilling or local flaps of soft tissue, tend to be ineffective. They should be carried out only when the pain is refractory to the remaining non-surgical treatments. 7,11 Surgical debridement sometimes does not achieve a vascularized surgical margin, as all the jaw is under the influence of the drug. According to Ruggiero, achieving a surgical re-section with viable bone margins is extremely difficult, although not impossible. Analgesics will be ad-ministered for treating the pain. $1,2,5,21$

The exposed necrotic bone that rubs and causes inflammation of the gums, oral or lingual mucosa should be put in order, in spite of the risk of increasing bone exposure. The fragments of sequestered bone should be removed, without touching the adjacent bone. Most of the procedures tend to lead to an in-crease in the area of necrotic bone exposed or the appearance of new areas. As a result of all these reasons, aggressive surgical or dental treatment in the oral cavity should be delayed or avoided as much as possible. ${ }^{23}$ If a 
ron los $\mathrm{BF}$, y sobre todo el Pamidronato y el ácido Zoledrónico. Desde el año 2003 se han publicado en la literatura varias series de casos en las que podría existir una posible relación entre los BF y la aparición de osteonecrosis a nivel de los maxilares.

En 2003 Wang y cols. publicaron 3 casos de osteonecrosis en hueso alveolar de pacientes en tratamiento con quimioterapia en asociación con BF (Pamidronato) por presentar metástasis óseas a consecuencia de cáncer de mama. Dos de esas pacientes presentaron la necrosis ósea tras exodoncia en la misma zona. En todos los casos se demostró la presencia de necrosis ósea y se descartó la posibilidad de ser una lesión metastásica. En un primer momento se atribuyó osteonecrosis al empleo de quimioterapia, pero posteriormente se sospechó la implicación de los BF.26

Marx y cols. publicaron una serie de 36 pacientes que habían recibido tratamiento intravenoso con BF (Pamidronato y ácido Zoledrónico) y que habían desarrollado una lesión necrótica a nivel de los maxilares. ${ }^{12}$ En la mayoría de los casos se habían realizado exodoncias, pero en cerca del $30 \%$ se había presentado de forma espontánea. Observaron que las lesiones se asemejaban a las debidas a la radionecrosis.

Migliorati y cols. describen un grupo de 5 pacientes en tratamiento con $\mathrm{BF}$ intravenosos que presentan necrosis ósea a nivel intraoral, en tres de los casos se había realizado una exodoncia previamente pero en los otros dos no se pudo identificar un desencadenante a nivel local. ${ }^{25}$

Los ensayos clínicos previos a la comercialización y utilización de estos fármacos no habían detectado estos efectos secundarios y ante el incremento de publicaciones sobre las necrosis en los maxilares a nivel mundial, en el 2004 la empresa Novartis junto con la FDA (Food and Drug Administration) realizan un comunicado alertando sobre el posible efecto de los BF y modifican las recomendaciones en el empleo de Zometa ${ }^{\circledR}$ y Aredia $^{\circledR}$.

Según Marx y Ruggiero la aparición de osteonecrosis en los maxilares se debe a que presentan un mayor aporte vascular y un remodelado óseo más rápido debido a la estimulación mecánica que producen las piezas dentales. 2,7,12,21 El riesgo de osteonecrosis aumenta con los procedimientos quirúrgicos y odontológicos que, junto con una mala higiene oral incrementan el riesgo de sobreinfección de dicho hueso necrótico al exponerse a la flora oral. Esto se traduce en dolor importante, tumefacción, supuración purulenta y exposición ósea.

Algunos autores como Dimitrakopoulos y cols. opinan que la interrupción de la administración de los BF, siempre que el estado del paciente lo permita, combinado con desbridamientos del hueso necrótico y antibioterapia puede ser el tratamiento adecuado de la osteonecrosis establecida. ${ }^{3}$ Por desgracia no se ha demostrado si la interrupción del tratamiento disminuye el riesgo de desarrollar osteonecrosis en pacientes que han recibido los BF durante años.

La Asociación Dental Americana (ADA) ha publicado en Agosto de 2006 una serie de recomendaciones para la práctica dental en pacientes en tratamiento con bifosfonatos y en aquellos que presenten osteonecrosis (BON-bisphosphonate associated osteonecrosis of the jaw). De igual manera, y para protocolizar los tratamientos, la Asociación Americana de Cirujanos Orales y Maxilofaciales surgical intervention in the oral cavity is undergone, prophylactic antibiotic treatment can be started 1 or 2 days before. The administration of antibiotics, in a continued or intermittent form, can be beneficial in some established osteonecrosis cases. Taking samples in order to carry out a culture and ad-ministering a specific antibiotic is recommended. Most of the germs that have been isolated are sensitive to beta-lactamase and therefore the antibiotic of choice is amoxicillin, alone or in conjunction with clavu-Ianic acid at a dose of $500 \mathrm{mg}$ three times a day and rinses with chlorhexidine at $0.12 \%$. Metronidazole at a dose of $250 \mathrm{mg}$ three times a day can in addition be used for more stubborn cases. Clindamycin can be used (300 $\mathrm{mg}$ three times a day) or Azitromycin (250 mg once a day) for allergic patients. Antibiotic treatment should be maintained for two weeks. According to Marx combining antibiotics and limited debridement is the best treatment option for exposed necrotic areas. ${ }^{2}$ Treatment with hyperbaric oxygen, which for osteoradionecrosis or osteomyelitis cases gives such good results, has not shown itself to be efficient for treating necrosisinduced BPs. ${ }^{24,25}$

\section{Discussion}

Over recent years a new complication has been described as part of the treatment for various patholo-gies (multiple myeloma, breast and prostrate cancer metastases, osteoporosis, malignant hypercalcemia, Paget's disease...), osteonecrosis of the jaw. In all these cases, the only factor in common was the use of BPs, and especially Pamidronate and Zoledronic acid. As from the year 2003 various series of cases have been published in the literature suggesting that there could be a possible relationship between BPs and the appearance of osteonecrosis of the jaw.

In 2003 Wang and cols. published 3 cases of osteonecrosis of alveolar bone in patients undergoing chemotherapy in conjunction with BPS (Pamidronate) because of bone metastases from breast cancer. Two of these patients had bone necrosis after an extraction in the same area. In all cases the presence of bone necrosis was demonstrated and the possibility of a metastatic lesion was ruled out. At first the osteonecrosis was attributed to the use of chemotherapy, but later it was suspected that BPs were involved. ${ }^{26}$

Marx and cols. published a series of 36 patients who had received BP treatment intravenously (Pa-midronate and Zoledronic acid) and who developed a necrotic lesion in the maxilla. ${ }^{12}$ In most cases ex-tractions had been carried out, but in nearly $30 \%$ this had been spontaneous. It was observed that the le-sions were like radionecrosis lesions.

Migliorati and cols. described a group of 5 patients with intraoral bone necrosis who were undergoing treatment with intravenous BPs. Three of the patients had previously had extractions but they were not able to detect locally what precipitated the necrosis in the other two patients. ${ }^{25}$ 
(AAOMS) ha publicado en el 2006 una guía de consenso en el manejo de los casos de osteonecrosis de los maxilares en pacientes en tratamiento con bifosfonatos (BRON-biphosphonate related osteonecrosis of the jaws). ${ }^{1}$ Los objetivos de estos grupos de expertos pueden resumirse en los siguientes puntos:

- Valoración de los riesgos y beneficios del tratamiento con bifosfonatos y la posibilidad de aparición de osteonecrosis.

- Diagnosticar los casos de osteonecrosis de los maxilares en pacientes con antecedente de tratamiento con bifosfonatos.

- Asesoramiento sobre las medidas de prevención y el tratamiento de pacientes que presenten osteonecrosis inducida por los bifosfonatos.

La incidencia de pacientes que desarrollan osteonecrosis y que están recibiendo BF es incierta hoy en día, pero lo más grave es que el número de casos que se detectan se está multiplicando. El posible papel de los BF en el inicio del desarrollo de la necrosis ósea avascular parece estar causada por la falta de aporte vascular y su efecto antiangiogénico. A día de hoy, se desconoce la influencia de variables como la duración del tratamiento, la vía de administración, las dosis recibidas y otros muchos factores de riesgo que contribuyen al desarrollo de las lesiones. Es preciso aportar más información por medio de estudios experimentales y de casos control para establecer de forma definitiva la relación causal entre los BF y la osteonecrosis de los maxilares.

\section{Conclusiones}

Los bifosfonatos son fármacos ampliamente utilizados a nivel mundial con unos claros beneficios contrastados clínicamente, que se traducen en una mejoría de la calidad de vida de los pacientes oncológicos con metástasis óseas y en una disminución de la incidencia de fracturas óseas en mujeres con osteoporosis posmenopáusica.

El tratamiento con bifosfonatos intravenosos parece ser un factor determinante en la aparición de osteonecrosis de los maxilares en pacientes oncológicos. Así mismo, la reciente publicación de un número cada vez mayor de casos de osteonecrosis en pacientes en tratamiento con bifosfonatos orales nos debe alertar.

El desencadenante de la exposición ósea es en la mayor parte de los casos una actuación quirúrgica por parte del cirujano oral y maxilofacial, odontólogo o estomatólogo. La osteonecrosis es una entidad de difícil manejo y tratamiento, en pacientes que suelen presentar previamente una calidad de vida disminuida por su proceso oncológico. Una correcta higiene bucal, revisiones periódicas y un tratamiento conservador o mínimamente agresivo se muestran como la conducta más recomendable.

Todavía no se ha demostrado una relación causal entre la necrosis y el uso de BF. No se dispone de datos confirmados acerca de si la suspensión del tratamiento con BF reduce el riesgo de osteonecrosis de los maxilares en pacientes que precisan tratamientos dentales. Son necesarias por tanto, nuevas investigaciones que clarifiquen la etiología de este trastorno, disminuyan su incidencia y aporten un tratamiento definitivo una vez que las lesiones estén presentes.
The clinical trials before the commercialization and use of these drugs did not detect secondary effects and, given the increase in the publications on necrosis of the jaw on a world scale, in 2004 the company Novartis together with the FDA (Food and Drug Administration) made an announcement warning of the possible effects of BPs and modifying the recommendations for the use of Zometa ${ }^{\circledR}$ and Aredia ${ }^{\circledR}$.

According to Marx and Ruggiero the appearance of osteonecrosis in the jaw is due to the greater blood supply and faster bone remodeling in the jaw due to the mechanical stimulation produced by the teeth. 2,7,12,21 The risk of osteonecrosis increases with surgical and dental procedures that, together with bad oral hygiene, increase the risk of additional infection of this necrotic bone, as there is exposure to oral flora. This results in considerable pain, swelling, purulent suppuration and bone exposure.

Some authors such as Dimitrakopoulos and cols. are of the opinion that the administration of BPs should be interrupted, providing the condition of the patient permits this, and that this, combined with debridement of the necrotic bone and antibiotherapy, could be suitable treatment for established osteone-crosis. ${ }^{3}$ Unfortunately, it has not been demonstrated whether interrupting the treatment of patients that have been undergoing BP treatment for years diminishes the risk of developing osteonecrosis. ${ }^{3}$

In August 2006, the American Dental Association (ADA) published a series of recommendations for dental practice in patients undergoing bisphosphonate therapy and for those with osteonecrosis (BON-bisphosphonate-associated osteonecrosis of the jaw). Similarly, and in order to have a treatment protocol, the American Association of Oral and Maxillofacial Surgeons (AAOMS) published in 2006 a consensus guide for the management of osteonecrosis cases of the jaw in patients undergoing treatment with bisphosphonate (BRON-bisphosphonate-related osteonecrosis of the jaw). ${ }^{1}$ The objectives of these expert groups can be summed up using the following points:

- The risks and benefits of bisphosphonate treatment should be evaluated together with the possibil-ity of osteonecrosis appearing.

- Osteonecrosis cases of the jaw should be diagnosed in patients with a history of bisphosphonate therapy.

- Advice should be given on prevention and treatment of patients with bisphosphonate-induced os-teonecrosis.

The incidence of patients who develop osteonecrosis and who are receiving BPs is uncertain today, but what is particularly serious is that the number of cases being detected is multiplying. The possible role of BPs in triggering the development of avascular bone necrosis appears to be caused by a lack of vascu-lar supply and an antiangiogenic effect. To date, the influence of variables such as treatment duration, administration method, dose received and many other risk factors contributing to the development of le-sions, is unknown. Providing more information through experimen- 


\section{Bibliografía}

1. American Dental Association Council on Scientific Affairs. Dental management of patients receiving oral bisphosphonate therapy: expert panel recommendations. J Am Dent Assoc 2006;137:1144-50.

2. Marx RE, Sawatari Y, Fortin M, Broumand V. Bisphosphonate-induced exposed bone (osteonecrosis/osteopetrosis) of the jaws: risk factors, recognition, prevention, and treatment. J Oral Maxillofac Surg 2005; 63:1567-75.

3. Dimitrakopoulos I, Magopoulos C, Karakasis D. Bisphosphonate-induced avascular osteonecrosis of the jaws: a clinical report of 11 cases. Int J Oral Maxillofac Surg 2006;35:588-93.

4. Lacy MQ, Dispenzieri A, Gertz MA, Greipp PR, Gollbach KL, Hayman SR, y cols. Mayo clinic consensus statement for the use of bisphosphonate in multiple myeloma. Mayo Clin Proc 2006;81:1047-53.

5. Leite AF, Figueiredo PT, Melo NS, Acevedo AC, Cavalcanti MG, Paula LM, y cols. Bisphosphonateassociated osteonecrosis of the jaws. Report of a case and literature review. Oral Surg Oral Med Oral Pathol Oral Radiol Endod 2006;102:14-21.

6. Berenson JR. Recommendations for zoledronic acid treatment of patients with bone metastases. Oncologist 2005;10:52-62.

7. Ruggiero SL, Mehrotra B, Rosenberg TJ, Engroff SL. Osteonecrosis of the jaws associated with the use of bisphosphonates: a review of 63 cases. J Oral Maxillofac Surg 2004;62:527-34.

8. Papapoulos SE, Hamdy NA, van der Pluijm G. Bisphosphonates in the management of prostate carcinoma metastatic to the skeleton. Cancer 2000;88:3047-53.

9. Van den Wyngaert T, Huizing MT, Vermorken JB. Bisphosphonates and osteonecrosis of the jaw: cause and effect or a post hoc fallacy? Ann Oncol 2006;17:1197-204.

10. Dannemann C, Grätz KW, Zwahlen R. Clinical experiences with bisphosphonateinduced osteochemonecrosis of the jaws. Swiss Med Wkly 2006;136:504-9.

11. Bagan JV, Murillo J, Jimenez Y, Poveda R, Milian MA, Sanchís JM, y cols. Avascular jaw osteonecrosis in association with cancer chemotherapy: series of 10 cases. I Oral Pathol Med 2005;34:120-3.

12. Marx RE: Pamidronate (Aredia) and zoledronate (Zometa) induced avascular necrosis of the jaws: A growing epidemic. / Oral Maxillofac Surg 2003;61:1115-7.

13. Ponte-Fernández N, Estefania-Fresco R, Aguirre-Urizar JM. Bisphos-phonates and Oral Pathology I. General and preventive aspects. Med Oral Patol Oral Cir Bucal 2006;11:396-400.

14. Carter G, Goss AN, Doecke C. Bisphosphonates and avascular necrosis of the jaws: A possible association. Med J Aust 2005;182:413-5.

15. Lugassy G, Shaham R, Nemets A, Ben-Dor D, Nahlieli O. Severe osteomyelitis of the jaw in longterm survivors of multiple myeloma: a new clinical entity. Am / Med 2004;117:440-1.

16. Maerevoet $\mathrm{M}$, Charlotte $\mathrm{M}$, Lionel $\mathrm{D}$. Osteonecrosis of the jaw and bisphosphonates. N Engl J Med 2005;353:99-102.

17. Melo MD, Obeid G. Osteonecrosis of the maxilla in a patient with a history of bisphosphonate therapy. J Can Dent Assoc 2005;71:111-3.

18. Sanna G, Zampino MG, Pelosi G, Nolé F, Goldhirsch A. Jaw avascular bone necrosis associated with longterm use of bisphosphonates. Ann Oncol 2005;16:1207-8.

19. Vannucchi AM, Ficarra G, Antonioli E, Bosi A. Osteonecrosis of the jaw associated with zoledronate theraphy in a patient with multiple myeloma. $\mathrm{Br} / \mathrm{Haematol}$ 2005; $128: 738$.

20. Badros A, Weikel D, Salama A, Goloubeva O, Schneider A, Rapoport A, y cols. Osteonecrosis of the jaw in multiple myeloma patients: clinical features and risk factors. / Clin Oncol 2006;24:945-52.

21. Ruggiero SL, Fantasia J, Carlson E. Bisphosphonate related osteonecrosis of the jaw: background and guidelines for diagnosis, staging and management. Oral Surg Oral Med Oral Pathol Oral Radiol Endod 2006;102:433-41.

22. Sambrook P, Olver I, Goss A. Bisphosphonates and osteonecrosis of the jaw. Aust Fam Physician 2006;35:801-3.

23. Pastor-Zuazaga D, Garatea-Crelgo J, Martino-Gorbea R, Etayo-Pérez A, SebastiánLópez C. Os-teonecrosis of the jaws and bisphosphonates. Report of three cases. Med Oral Patol Oral Cir Bucal 2006;11:76-9.

24. Nase JB, Suzuki JB. Osteonecrosis of the jaw and oral bisphosphonate treatment. J Am Dent Assoc 2006;137:1115-9.

25. Migliorati CA, Casiglia J, Epstein J, Jacobsen PL, Siegel MA, Woo SB. Managing the care of patients with bisphosphonate-associated osteonecrosis: An American Academy of Oral Medicine position paper. J Am Dent Assoc 2005;136:1658-68.

26. Wang J, Goodner NM, Pogrel MA. Osteonecrosis of the jaws associated with cancer chemoterapy. J Oral Maxillofac Surg 2003;61:1104-7. tal studies and control cases is neces-sary in order to establish definitively the causal relationship between BPs and osteonecrosis of the jaw.

\section{Conclusions}

Bisphosphonates are drugs that are widely used on a worldwide scale with clear benefits that have been clinically proven. They result in a quality of life improvement for oncological patients with bone metastases and to a reduction in the incidence of bone fractures in women with postmenopausal osteopo-rosis.

Intravenous bisphosphonate therapy appears to be a determining factor in the appearance of osteone-crosis of the jaw in oncological patients. Thus, the recent publication of an ever-greater number of os-teonecrosis in patients undergoing oral bisphosphonate therapy should alert us.

What triggers bone exposure is generally surgical action taken by oral and maxillofacial surgeons, odontologists or dentists. Osteonecrosis is an entity that is difficult to manage and treat, as these patients tend to have a reduced quality of life because of their oncological condition. Correct oral hygiene, peri-odic revisions and conservative or minimally aggressive treatment, are the best recommendations for managing this condition.

A causal relationship has still to be demonstrated between necrosis and the use of BPs. There are no data available that would confirm if, by suspending BP therapy, the risk of osteonecrosis of the jaw is reduced in patients requiring dental treatment. New investigation is therefore needed in order to clarify the etiology behind this disorder, to reduce the incidence rate and to provide definitive treatment once these lesions appear. 